\title{
Novel mutations associated with combined pituitary hormone deficiency
}

\author{
Christopher J Romero, Elyse Pine-Twaddell and Sally Radovick \\ Division of Pediatric Endocrinology, Department of Pediatrics, The Johns Hopkins University School of Medicine, 600 North Wolfe Street, \\ CMSC 406, Baltimore, Maryland 21208, USA \\ (Correspondence should be addressed to S Radovick; Email: sradovick@jhmi.edu)
}

\begin{abstract}
The pituitary gland produces hormones that play important roles in both the development and the homeostasis of the body. A deficiency of two or several of these pituitary hormones, known as combined pituitary hormone deficiency, may present in infants or children due to an unknown etiology and is considered congenital or idiopathic. Advancements in our understanding of pituitary development have provided a genetic basis to explain the pathophysiological basis of pituitary hormone disease. Nevertheless, there are several challenges to the precise characterization of abnormal genotypes; these exist secondary to the complexities of several of the hypothalamic/pituitary developmental factors and signals, which ultimately integrate in a temporal and spatial dependent manner to produce a mature gland. Furthermore, the clinical presentation of pituitary hormone disease may be dynamic as subsequent hormone deficiencies may develop over time. The characterization of patients with mutations in genes responsible for pituitary development provides an opportunity to discover potential novel mechanisms responsible for pituitary pathophysiology. The focus of this review is to report the most recent mutations in genes responsible for pituitary development in patients with hypopituitarism and emphasize the importance to physicians and researchers for characterizing these patients. Continuing efforts toward understanding the molecular basis of pituitary development as well as genetic screening of patients with pituitary disease will offer new insights into both diagnostic and potential therapeutic options that will decrease the morbidity and mortality in patients with hypopituitarism.
\end{abstract}

Journal of Molecular Endocrinology (2011) 46, R93-R102

\section{Introduction}

The development of the human pituitary has been mapped to the expression of transcription factors in a coordinated temporal and spatial sequence that ultimately produces five distinct pituitary cell types. These cell types (along with the hormone product) include the somatotroph $(\mathrm{GH})$, thyrotroph (TSH), lactotroph (prolactin (PRL)), gonadotroph (FSH and LH), and corticotroph (ACTH). Our knowledge regarding pituitary embryogenesis has been gained from experimental animal models, which have helped to categorize developmental genes necessary for pituitary development and function (Dasen \& Rosenfeld 2001, Scully \& Rosenfeld 2002, Kelberman \& Dattani 2006). These transcription factors, in addition to signaling molecules, initiate the formation of Rathke's pouch and direct the proliferation of cells into distinct cell lineages. Any disruption of this cascade adversely affects the development or survival of single or multiple cell types, thus ultimately leading to deficiencies in hormone products.
In humans, combined pituitary hormone deficiency (CPHD) is diagnosed when the production of two or more of these hormones is insufficient or absent. The etiology of CPHD is typically multifactorial and may be secondary to a neurological insult. However, a subset of patients, who present during infancy or childhood with CPHD, is classified as having idiopathic disease. These patients may be considered to have a genetic etiology for their deficiencies, associated with mutations in several of these transcription factors responsible for pituitary development. Although the incidence of reported mutations in CPHD patients remains low, current research continues to delineate the complexities of pituitary development and more clearly define the molecular basis of hormone deficiency in these patients.

\section{Pituitary developmental factors}

The identification and characterization of pituitary developmental factors in vivo and in vitro has helped to

DOI: 10.1530/JME-10-0133 Online version via http://www.endocrinology-journals.org 
establish a genetic basis for CPHD in humans who harbor similar mutations. These factors include HESX1, LHX3, LHX4, POU1F1, PROP1, SIX6, OTX2, PTX2, GLI2, and $S O X 3$, all of which have been shown to play a role in the development and maturation of the pituitary gland. For example, the Hesx 1 mutant mouse model demonstrates forebrain and pituitary malformation along with abnormalities in the septum pellucidum and eye. This phenotype is similar to the human phenotype of septooptic dysplasia (SOD; Dattani et al. 1998). Despite the identification of several HESX1 mutations in patients with SOD, reports state that $<1 \%$ of patients with SOD demonstrate coding region mutations (Cohen et al. 1999a, Thomas et al. 2001, Tajima et al. 2003, Sobrier et al. 2006, Coya et al. 2007, McNay et al. 2007). Consequently, the incidence of identifying a mutation in humans remains low, but this may simply reflect that other factors or signaling molecules remain to be identified (Reynaud et al. 2006). Figure 1 illustrates a modified overview of pituitary development that has been adapted from previous embryological studies of mice. This cascade of events emphasizes the importance of both the temporal and the spatial expression of both developmental factors and signals required for the

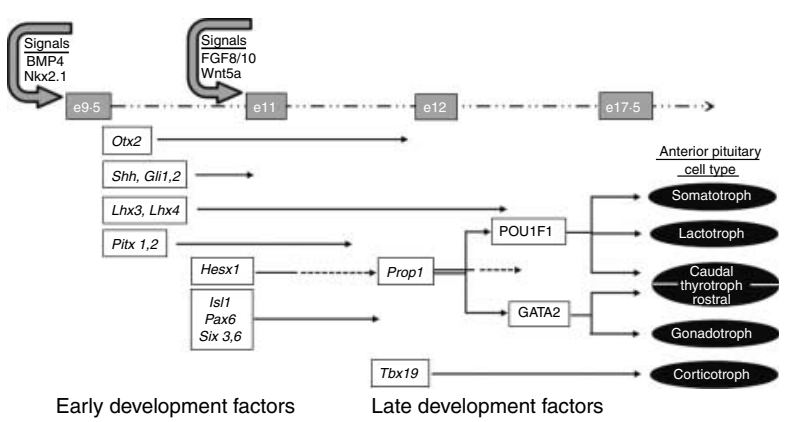

Figure 1 Expression of developmental factors and signals required for anterior pituitary development. A modified overview of murine pituitary development adapted from previous embryological studies illustrates the sequence of events that determine the proliferation and differentiation of mature pituitary cell types. Initially, contact of the oral ectoderm with the neural ectoderm followed by a cascade of events consisting of both signaling molecules and transcription factors expressed in a specific temporal and spatial fashion leads to the development of Rathke's pouch (RP). At embryological day 9.5 (e9.5), expression of BMP4 and Nkx2.1 along with sonic hedgehog (Shh) initiates the development of the primordial RP. The expression of the factors Gli1, Gli2, Lhx3, Pitx1, and Pitx2 result in the development of progenitor pituitary cell types. These events are followed by the expression of HESX1, ISL1, PAX6, SIX3, and SIX6, which are important for cellular development, proliferation, and migration. The attenuation of Hesx1 (dotted arrows at $\sim$ e12.5) is required for the expression of Prop1. By e12.5, RP has formed and by e17.5, differentiation of specific pituitary cell types has been completed. The mature pituitary gland contains the differentiated cell types: somatotrophs, lactotrophs, thyrotrophs, gonadotrophs, and corticotrophs (Dasen \& Rosenfeld 2001, Scully \& Rosenfeld 2002, Kelberman \& Dattani 2006, Zhu et al. 2007). appropriate differentiation and proliferation of the mature pituitary cell types (Fig. 1).

The focus of this review is to inform the reader of recently reported mutations in the most commonly studied transcription factors since $\sim 2001$. Although some of the factors have been implicated in hypopituitarism for more than a decade, this review is not intended to present the reader with a comprehensive list of DNA abnormalities in these patients. We hope to highlight the current advancements in molecular genetics that have allowed researchers to not simply identify mutations or deletion of genes but more importantly provide potential mechanisms of pathology through the use of functional studies.

CPHD has a wide spectrum of presentations and quite often hypopituitarism is a developing entity as patients may acquire hormone deficiencies overtime. The range of clinical presentations emphasizes the complexity of pituitary development and suggests that both compensatory mechanisms, as well as interplay between transcription factors, ultimately determine the fate of pituitary function.

\section{HESX1}

The human HESX1 gene, located on chromosome 3 p14.3, contains a 185 amino acid open reading frame with four exons and acts as a promoter-specific transcriptional repressor (Dattani et al. 1998, Brickman et al. 2001). In early development, Hesx 1 transcripts are expressed in the anterior visceral endoderm and neural ectoderm but are eventually restricted to the Rathke's pouch (Hermesz et al. 1996, Thomas \& Beddington 1996, Andoniadou et al. 2007). Its role as a repressor has been demonstrated by its downregulation, which precedes a rise in PROP1 at mouse embryonic day 12 (e12). Pituitary development continues as the DNA binding motif of HESX1 in the presence of PROP1 changes to preferentially bind with PROP1 as a heterodimer (Kato et al. 2010). More recently, the complexities of HESX1's role in pituitary development have been demonstrated through its association with other pituitary factors during development. Table 1 lists several reported interactions between HESX1 and other factors that when perturbed can affect pituitary development. The discovery and characterization of these interactions for HESX1 and other developmental factors are important steps in not only delineating pituitary development but also understanding clear mechanisms of pathology in hypopituitarism (Gaston-Massuet et al. 2008, Sajedi et al. 2008a, Carvalho et al. 2010).

In humans, clinical manifestations of mutations in the HESX1 gene are variable and contribute to CPHD or as part of SOD with an inheritance pattern classified as either autosomal recessive or autosomal dominant 
Table 1 Factors reported to interact with HESX1

$\begin{array}{ll}\text { Transcription factor } & \begin{array}{l}\text { Role } \\ \text { SIX3 }\end{array} \\ & \begin{array}{l}\text { Homeobox transcription } \\ \text { factor important for eye and } \\ \text { pituitary development }\end{array}\end{array}$

DNA methyltransferase 1 (DNMT1)

Nuclear protein for $\mathrm{CpG}$ DNA-methylation and gene regulation coexpressed with HESX1 and acts as binding protein

Groucho-related co-repressors that bind to transcription factors

TLE1/TLE3
Pituitary-specific homeobox transcription factor
Mechanism of interaction Functional studies

Regulates through the WNT/ $\beta$-catenin signaling pathway to allow normal forebrain development

May induce permanent gene silencing by the specific methylation of CpG residues of HESX1 target genes

Augment repressor role of HESX1

The presence of PROP1 leads to HESX1 motif change: TAATT to TAAT forming heterodimer with HESX1; such interaction allows PROP1 to advance pituitary development

\begin{tabular}{|c|c|}
\hline Functional studies & References \\
\hline $\begin{array}{l}\text { Six3+/- Hesx } 1 \text { Cre/+ } \\
\text { compound heterozygote } \\
\text { mice demonstrate } \\
\text { postnatal dwarfism, low } \\
\text { thyroid function, and poor } \\
\text { testicular development; } \\
\text { abnormal pituitary } \\
\text { phenotype secondary to } \\
\text { disrupted signaling }\end{array}$ & $\begin{array}{l}\text { Gaston-Massuet } \\
\text { et al. (2008) }\end{array}$ \\
\hline $\begin{array}{l}\text { Transfected 293T cells } \\
\text { demonstrate that HESX1 } \\
\text { and DNMT1 form } \\
\text { complexes; in situ hybrid- } \\
\text { ization with wild-type } \\
\text { mouse embryos suggest } \\
\text { that HESX1 may repress } \\
\text { transcription through } \\
\text { methylation of targets }\end{array}$ & $\begin{array}{r}\text { Sajedi et al. } \\
(2008 a, b)\end{array}$ \\
\hline $\begin{array}{l}\text { Transfected 293T cells } \\
\text { demonstrate TLE1 and } \\
\text { TLE3 augment HESX1 } \\
\text { repression of PROP1; } \\
\text { transgenic mice with } \\
\text { ectopic TLE3 and HESX1 } \\
\text { expression disrupt } \\
\text { differentiation of thyro- } \\
\text { trophs and gonadotrophs }\end{array}$ & $\begin{array}{l}\text { Carvalho } \\
\quad \text { et al. (2010) }\end{array}$ \\
\hline $\begin{array}{l}\text { Used random oligonucleo- } \\
\text { tides and an electro- } \\
\text { phoretic mobility shift assay } \\
\text { to examine binding prefer- } \\
\text { ence of HESX1 }\end{array}$ & $\begin{array}{l}\text { Kato } \\
\quad \text { et al. (2010) }\end{array}$ \\
\hline
\end{tabular}

with incomplete penetrance. This correlates with murine models bearing Hesx 1 mutations, which bear midline cranial defects along with pituitary and eye abnormalities similar to SOD (Dattani et al. 1998). A diagram summarizing the most recent HESX1 mutations and their position in reference to their exon are shown in Fig. 2. A novel p.I26T mutation in exon 1 was reported in a patient with early GH deficiency (GHD), FSH/LH deficiency, and evolving TSH and cortisol deficiency, along with pituitary structural abnormalities (Carvalho et al. 2003). Although mutations in HESX1 associated with pituitary disease appear to modulate the DNA-binding affinity of HESX1, this mutation appeared to impair transcriptional repression (Brickman et al. 2001, Carvalho et al. 2003).

A group of investigators further studied this mutation through the generation of a mouse model with Hes 1 mutations p.I26T and p.R160C in order to demonstrate the effects of HESX1 on embryonic development. Both mutations had complete penetrance of pituitary defects; however, the effect on ocular and forebrain development varied with the I26T/I26T less severely affected than I26T/(null). The authors suggested that the pituitary may be more sensitive to dosage reductions of HESX1 than the eye and forebrain (Sajedi et al. 2008b).

More recently, a report of a homozygous frameshift mutation, c.449_450delAC (E150delX167), and a splice defect, c. $357+2 \mathrm{~Tb}>\mathrm{C}$, was demonstrated to interfere with the translation of the homeodomain (Sobrier et al. 2006). Functional studies of the mutated HESX1 demonstrated failure to repress PROP1 activity versus wild-type HESX1, which repressed gene activation. Each patient exhibited severe CPHD and magnetic resonance imaging (MRI) abnormalities, but normal optic nerves, and anterior pituitary (AP) aplasia with a flat sella turcica.

\section{LHX3}

The LHX3 transcription factor maps to the subtelomeric region of chromosome 9 at band 9q34.3 and contains seven exons and six introns (Sloop et al. 2001). The protein possesses two LIM domains involved in 


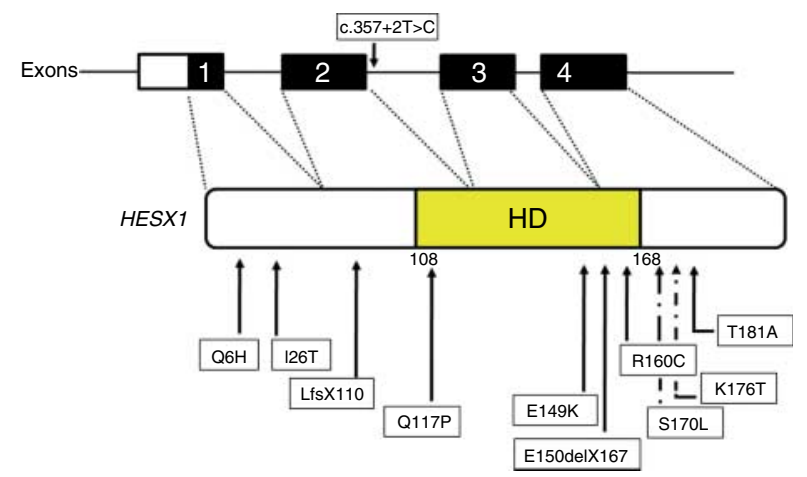

Figure 2 Reported HESX1 gene mutations associated with human CPHD since 2001. The coding exons are illustrated in the top line, whereas the HESX1 mRNA structure is shown below with the homeodomain (HD) region in yellow color. The location of reported mutations is indicated by the arrows.

protein-protein interactions, a DNA binding homeodomain and a carboxyl terminus that contains the major transactivation domain. In humans, the identification and study of two isoforms, LHX3a and LHX3b, demonstrates that these factors differentially activate genes, although LHX3a appears to be the most active isoform (Sloop et al. 1999, West et al. 2004, McGillivray et al. 2005). In humans, homozygous loss-of-function mutations in $L H X 3$ have been identified in patients with hypopituitarism including GH, TSH, PRL, LH, and FSH deficiencies and AP defects and cervical abnormalities with or without restricted neck rotation. ACTH deficiency has also been diagnosed in a subset of patients. Figure 3 illustrates the coding exons of $L H X 3 a$ along with the location of reported human mutations in this gene.

A recent published report of six patients diagnosed with CPHD, restricted neck rotation, scoliosis, and congenital hearing impairment was found to have a novel splice acceptor site mutation in intron 3 with recessive inheritance (Kristrom et al. 2009). In another group of patients with CPHD, severe AP hypoplasia, skeletal abnormalities, and bilateral sensorineural hearing loss and also in one family hyperextensible joints and loose skin and two homozygous recessive mutations were reported: an intragenic deletion of 3008 bp resulting in complete loss of exons $2-5$ and in an unrelated family a homozygous transversion c. $267 \mathrm{~A}>\mathrm{T}$ that led to a nonsense mutation in exon 2 (Rajab et al. 2008). The authors of this study also demonstrated an association of LHX3 and the transcription factor SOX2, in which SOX2 may play a role in the regulation of LHX3 expression and therefore function in pituitary development (Rajab et al. 2008). A group of investigators reported four novel recessive mutations in four consanguineous pedigrees after screening 366 patients diagnosed with isolated GHD (IGHD) or CPHD. These included two homozygous mutations, p.E173ter and p.W224ter in exons 3 and 5 respectively, that lead to truncated proteins, a mutation in the homeodomain (p.A210V), and a homozygous gene deletion. All patients had CPHD; however, a hypoplastic pituitary or limited neck rotation was not universal (Pfaeffle et al. 2007). In an earlier study, a patient was identified to have a p.159delT (exon 2 delT) $L H X 3$ mutation causing a frameshift and premature termination codon. The patient was diagnosed with deficiencies of GH, PRL, LH, FSH, and TSH, a rigid cervical spine with limited head rotation, mental retardation, and MRI findings of a hypodense lesion in the pituitary consistent with a microadenoma. The authors suggest that mutations in $L H X 3$ may also lead to abnormal pituitary cell proliferation (Bhangoo et al. 2006).

\section{LHX4}

The human LHX4 gene, located on chromosomal position 1q25 with six exons encoding 390 amino acids, is another member of the LIM homeodomain of transcription factors required for the development of Rathke's pouch (Machinis et al. 2001, Liu et al. 2002, Reynaud et al. 2004, Pfaeffle et al. 2008). The Lhx4 $(-/-)$ mutant mouse demonstrated all five AP cell lineages; however, there are reduced numbers leading to a hypoplastic lobe (Sheng et al. 1997). Further studies of LHX4 in conjunction with LHX3 demonstrate that LHX4 is required for the proliferation of lineage precursors, whereas LHX3 is necessary to establish the fate of pituitary precursor cells (Sheng et al. 1997).

The clinical manifestations of LHX4 mutations encompass a varied presentation including GHD and variable TSH, gonadotropin, and ACTH deficiencies. Figure 4 illustrates the position, in reference to the exon, of recently reported mutations diagnosed in patients with CPHD. A p.A210P mutation within the homeodomain was found in a father and two daughters,

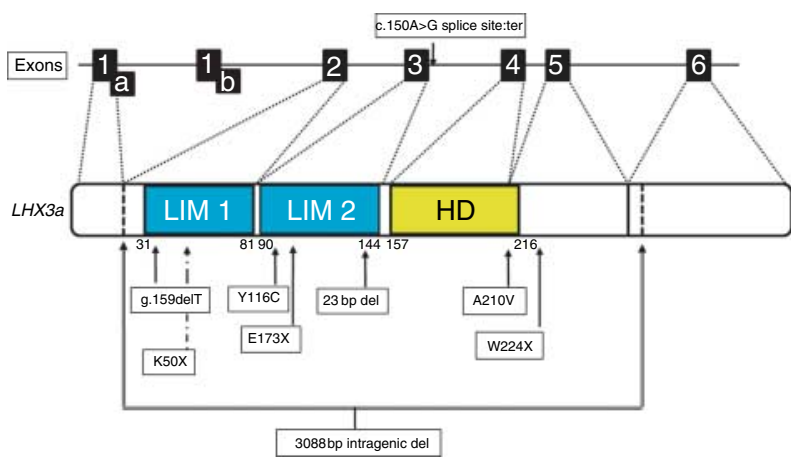

Figure 3 Reported $L H X 3$ gene mutations associated with human combined pituitary hormone deficiency. The figure illustrates the coding exons (boxes) and the LHX3a mRNA structure with the coding regions for the LIM domains and the homeodomain (HD). The location of reported mutations is indicated by the arrows. 


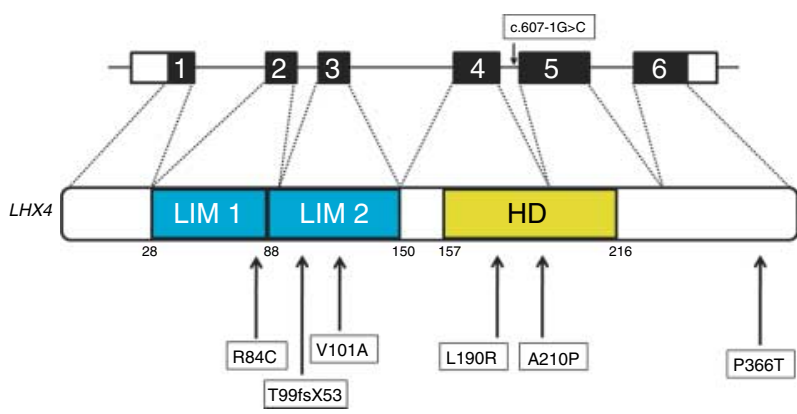

Figure 4 Reported $L H X 4$ gene mutations associated with human CPHD since 2001. The coding exons are seen in the first line with the translated regions in black color. The LHX4 mRNA structure is depicted below with the coding regions for the LIM domains and the homeodomain (HD) shown in blue and yellow color respectively. The location of reported mutations is indicated by the arrows.

with one sister diagnosed with CPHD whereas the other sister and father had GHD only (Pfaeffle et al. 2008). Another patient with a p.L190R mutation also in the homeodomain was deficient in GH, ACTH, and TSH (Pfaeffle $e t$ al. 2008). A third patient with GHD, TSH deficiency, and gonadotropin deficiency was found to have a p.R84C mutation located between the LIM domains of the protein. Functional studies of these mutations demonstrated either a reduced or abolished capacity to activate an $\alpha \mathrm{GSU}$ reporter. Despite the previous association of $L H X 4$ mutations with cerebellar abnormalities, the imaging of these three cases demonstrated only a hypoplastic AP with or without an ectopic posterior pituitary (PP). More recently, a novel mutation, p.V101A in the LIM2 domain in exon 3, was found in a patient with CPHD, a small AP, and ectopic PP. This mutation demonstrated an inability to activate the $P O U 1 F 1$ and FSH $\beta$ subunit gene promoter, indicating a loss of function mutation (Tajima et al. 2009a). This finding highlights previous findings suggesting that POU1F1 is an LHX4 target leading to the expression of GH (Machinis \& Amselem 2005). Another familial mutation resulting in CPHD and pituitary abnormalities was identified as a $\mathrm{C}$ insertion into the third exon of $L H X 4$, resulting in a frameshift mutation with an early stop codon (p.Thr99fs; Castinetti et al. 2008). Functional and structural studies of the mutant LHX4 demonstrated a complete loss of transcriptional activity on the POU1F1 promoter and a lack of DNA binding (Castinetti et al. 2008).

\section{Prophet of Pit1}

The human Prophet of Pit1 (PROP1) gene, located at chromosomal position 5q35, with three exons encoding 226 amino acids, contains both a paired-like homeodomain for DNA binding and a C-terminal transcriptional activator domain (Duquesnoy et al. 1998). PROP1 acts as both a repressor in downregulating
HESX1 and as an activator of POU1F1 (Dasen \& Rosenfeld 2001). A proposed mechanism is through the Wnt/ $\beta$-catenin signaling pathway, in which the binding of PROP1 with $\beta$-catenin represses Hesx1 expression and promotes POU1F1-dependent cellular development (Olson et al. 2006). The expression of PROP1 maintains the POU1F1 lineage and allows for differentiation of lactotrophs, somatotrophs, and thyrotrophs. It has been shown to be dependent on Notch signaling, which is thought to be important for late lineage differentiation (Zhu et al. 2006). The Ames mouse, which harbors a mutated Prop1, demonstrates severe dwarfism, hypothyroidism, and infertility (Sornson et al. 1996). Recently, Ward et al. (2007) created a Prop1 bacterial artificial chromosome transgene, which rescued the mutant mice with the Prop1 dwarf phenotype when crossed with wild-type mice.

The frequency of human PROP1 mutations remains low among sporadic cases but accounts for $29 \cdot 5-50 \%$ of familial cases of CPHD (Turton et al. 2005a, Kelberman \& Dattani 2006). There are at least 24 reported mutations, which have either homozygous recessive or compound heterozygous inheritance (Kelberman \& Dattani 2007). Figure 5 illustrates recently reported human mutations associated with CPHD and the mutation location in reference to the exon affected. The clinical phenotypes of human PROP1 mutations may be variable and dynamic. Typically, patients present with GH, PRL, and TSH deficiencies, although there may be increased risk for cortisol and gonadotropin deficiency with age. Structurally, there is a normal PP and stalk, but the AP may be hypoplastic, normal, or enlarged, which may wax and wane before

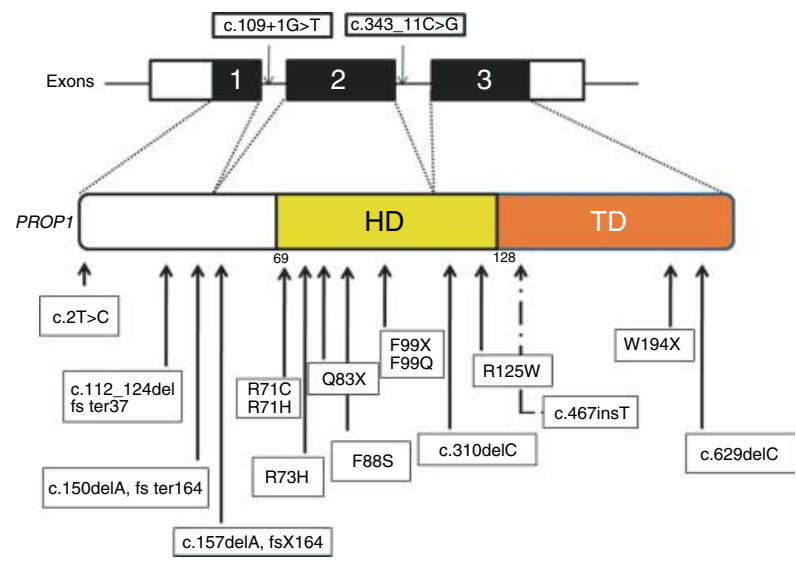

Figure 5 Reported PROP1 gene mutations associated with human CPHD since 2001. The coding exons are illustrated in the first line with the translated regions depicted in black color. The PROP1 mRNA structure is shown below with homeodomain (HD) and the transactivation domain (TD) in yellow and orange colors respectively. The relative positions of reported mutations are indicated by the arrows. 
eventual involution (Turton et al. 2005a, Kelberman \& Dattani 2007).

The majority of reported mutations involves the DNA-binding homeodomain and in part the transcription domain (as depicted in Fig. 5). There was a recent description of a mutation, however, in the initiation codon in $\mathrm{c} .2 \mathrm{~T} \rightarrow \mathrm{C}$ in two sisters who were diagnosed with pituitary hypoplasia and CPHD in addition to late onset of adrenal insufficiency. This first described exon 1 mutation resulted in loss of translation of the PROP1 protein (Lemos et al. 2006). Another novel homozygous mutation upstream of the homeodomain, microdeletion c.112_124, was described in three family members with CPHD from a large consanguineous family (Agarwal et al. 2000). This mutation leads to a premature termination codon that resulted in a protein lacking the homeodomain and transactivation domain. Deletions of the entire PROP1 gene have also been reported in patients with CPHD, which is similar to those harboring a small deletion, thus suggesting that even a small deletion could result in the loss of activity in vivo (Abrao et al. 2006, Kelberman et al. 2008a,b).

\section{POU1F1 (PIT1)}

The human POU1F1 gene, located on chromosome $3 \mathrm{p} 11$, is composed of six exons and has two protein domains: a POU-specific domain and a POU homeodomain (Rosenfeld 1991, Tatsumi et al. 1992). Both domains are important in high-affinity DNA binding of genes encoding GH and PRL as well as in the regulation of TSH $\beta$, cAMP, and PRL production (Xu et al. 1998, Cohen et al. 1999a). Furthermore, there is evidence to suggest that additional regulation of POU1F1 expression includes retinoic acid induction of the POU1F1 gene distal enhancer during pituitary development (Cohen et al. 1999b). A more recent advancement in our understanding of POU1F1 expression and regulation includes a novel pituitary regulator known as Atbf1, which is a transcription factor belonging to the 'giant, multiple-homeodomain, and zinc finger family' (Qi et al. 2008). Atbf1 mutant mice demonstrated a decrease of POU1F1 mRNA expression along with diminished expression of $\mathrm{GH}$ and $\mathrm{TSH} \beta$, although products of non-Pit1-dependent cell types such as corticotrophs and melanotrophs were unaffected.

The clinical manifestations of POU1F1 mutations have been well described in patients and include GH, TSH, and PRL deficiency with inconsistent MRI findings of AP hypoplasia. At least 27 different mutations have been described, with both autosomal recessive and dominant negative inheritance (Kelberman et al. 2009). Recently reported POU1F1 mutations in patients diagnosed with CPHD are illustrated in Fig. 6. A study of 129 patients with CPHD found POU1F1 mutations in ten patients, of whom five had the R271W mutation, a site considered

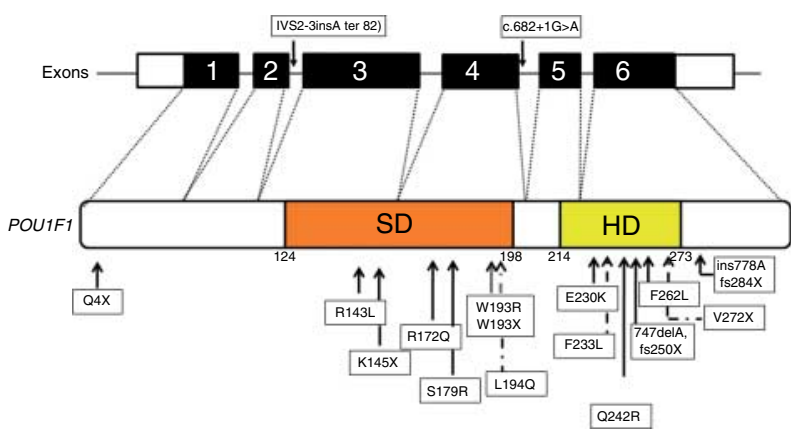

Figure 6 Reported POU1F1 gene mutations associated with human CPHD since 2001. The coding exons are illustrated in the first line with the translated regions depicted in black color. The POU1F1 mRNA structure is shown below with POU-specific domain (SD) and the POU-homeodomain (HD) in orange and yellow colors respectively. The relative positions of reported mutations are indicated by the arrows.

a mutational 'hotspot' (Turton et al. 2005b). Despite a majority of mutations reported as missense/nonsense, a homozygous c. $682+1 \mathrm{G}>\mathrm{A}$ intronic splice site mutation affecting the exon 4 splice donor site was described in a patient with GH, TSH, and PRL deficiency and a hypoplastic AP (Snabboon et al. 2008). A more recent novel mutation, an IVS2-3insA mutation adjacent to the splicing site, was reported to generate a premature stop codon that resulted in loss of the homeodomain and transactivation domain (Carlomagno et al. 2009). The function of POU1F1, furthermore, also shares an important relationship with cyclic AMP response element binding protein (CBP). A 20-year-old man with congenital CPHD and a hypoplastic AP gland was reported to have a mutation in exon 4, p.S179R, identified in the POU-specific domain. Functional studies revealed decreased transactivation of $\mathrm{GH} 1$, PRL, POU1F1, and TSH $\beta$ promoters (Miyata et al. 2006). The authors demonstrated that both DNA binding and interaction with co-activators such as CBP are critical to POU1F1's function (Miyata et al. 2006).

\section{OTX2}

OTX2, a member of the orthodenticle family located on chromosome 14q23.1, is expressed early in anterior neuroectoderm development and is known for its critical role in retinal photoreceptor, rostral brain, and midbrain development (Acampora et al. 2000, Kurokawa et al. 2004, Henderson et al. 2009). Although mutations in OTX2 are commonly associated with eye abnormalities, several reports demonstrate its importance in pituitary function. A recent short report that reviewed reported OTX2 mutations states that abnormal pituitary structure and/or function occurred in $\sim 30 \%$ of patients with mutations (Schilter et al. 2010). Figure 7 illustrates several of the most recently reported 


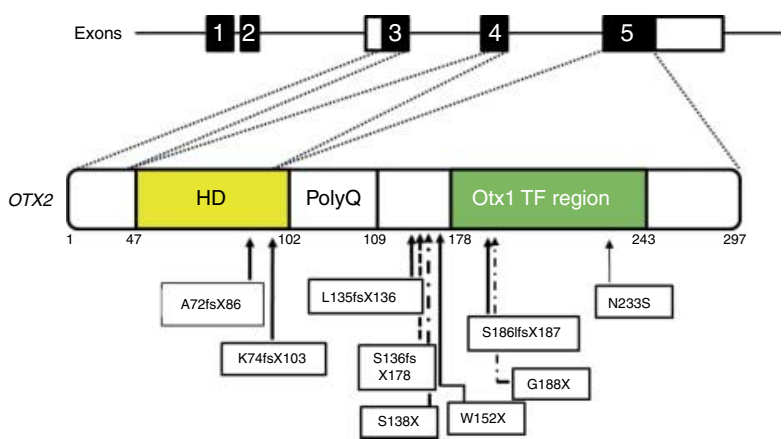

Figure 7 Reported OTX2 gene mutations associated with human CPHD. OTX2 is organized into five exons of which only three are translated (black boxes) as shown in the first line. The OTX2 mRNA structure is below with the coding regions for the homeodomain (HD) and the Otx1 transcription factor (TF) regions colored in yellow and green respectively. The location of reported mutations in patients diagnosed with hormone deficiencies $+/-$ eye abnormalities is indicated by the arrows.

OTX2 mutations in patients whose clinical presentation included abnormal pituitary function. In four patients, three novel heterozygous mutations were reported, which include frameshift and nonsense mutations along with a microdeletion of approximately a $2.9 \mathrm{Mb}$ deletion that includes OTX2 (Dateki et al. 2009). Interestingly, two patients were diagnosed with IGHD, one patient with CPHD and two cases with normal pituitary function, yet all patients had ocular abnormalities. The authors demonstrated either reduced or lost transactivation of four promoters including GNRH1, HESX1, POU1F1, and IRBP promoters by these mutations compared with the wild-type gene. This same group also reported a de novo heterozygous frameshift mutation in a patient with IGHD and bilateral anophthalmia that led to a loss of the OTX2 transactivation region (Dateki et al. 2008). Brain structural abnormalities along with CPHD and anophthalmia were reported in a boy who was found to have a heterozygous 2 base insertion in the third translated exon of OTX2 [p.S136fsX178 (c.576577insCT) ] (Tajima et al. 2009b). The mutant OTX2 demonstrated an inability to activate the promoters in the HESX1 and POU1F1 genes.

Furthermore, two unrelated patients diagnosed with CPHD and pituitary gland structural abnormalities, but without ocular pathology, were described to harbor a heterozygous OTX2 mutation in the third translated exon (p.N233S) (Diaczok et al. 2008). Despite preserved binding to target genes, the mutant was shown to act as a dominant negative inhibitor of HESX1 gene expression. Finally, Henderson et al. (2009) performed a screening for OTX2 mutations in 142 patients with eye abnormalities. The authors described a de novo heterozygous p.S138X stop mutation in a seven-year-old male who was also noted to have GHD with a normal MRI. Although OTX2 mutations are rare and often associated with eye abnormalities, these studies highlight the role of OTX2 in pituitary pathology as well as the broad spectrum of phenotypes associated with mutations in this gene.

\section{Concluding remarks}

Over the past two decades, the pursuit of establishing a genetic basis for the development of idiopathic hypopituitarism has yielded great insight into the mechanisms involved in pituitary development. As more physicians become aware of centers that offer DNA screening in patients with CPHD, we observe increasing number of reports of novel mutations in pituitary developmental factors, which may provide an etiology for a patient's pituitary pathology. The reader should recognize that this review is not comprehensive and, additional reports in patients with CPHD who were found to have mutations in factors such as GLI2, SOX2, SOX3, and others have been reported (Roessler et al. 2003, Woods et al. 2005, Kelberman et al. 2006, 2008a,b, Solomon et al. 2007). Furthermore, the characterization of several developmental factors using functional studies has demonstrated that they are interactive and interdependent to ultimately determine cellular function as well as cell survival. This is most likely why hypopituitarism has a heterogeneous clinical phenotype and often a continuum of evolving pathology. Nonetheless, the discovery of single-gene mutations since the 1990s has helped further the advances in mutation detection and offered insights into genotype/ phenotype correlation. Understanding the genetics of pituitary pathology offers a chance to improve both the morbidity and the mortality often associated with CPHD. More importantly, the advancing science of gene therapy will someday relieve many patients from the burden of hormone replacement and provide the opportunity for a potential cure.

\section{Declaration of interest}

The authors declare that there is no conflict of interest that could be perceived as prejudicing the impartiality of the research reported.

\section{Funding}

This research did not receive any specific grant from any funding agency in the public, commercial, or not-for-profit sector.

\section{References}

Abrao MG, Leite MV, Carvalho LR, Billerbeck AE, Nishi MY, Barbosa AS, Martin RM, Arnhold IJ \& Mendonca BB 2006 Combined 
pituitary hormone deficiency (CPHD) due to a complete PROP1 deletion. Clinical Endocrinology 65 294-300. (doi:10.1111/j.13652265.2006.02592.x)

Acampora D, Gulisano M \& Simeone A 2000 Genetic and molecular roles of otx homeodomain proteins in head development. Gene $\mathbf{2 4 6}$ 23-35. (doi:10.1016/S0378-1119(00)00070-6)

Agarwal G, Bhatia V, Cook S \& Thomas PQ 2000 Adrenocorticotropin deficiency in combined pituitary hormone deficiency patients homozygous for a novel PROP1 deletion. Journal of Clinical Endocrinology and Metabolism 85 4556-4561. (doi:10.1210/jc.85.12. 4556)

Andoniadou CL, Signore M, Sajedi E, Gaston-Massuet C, Kelberman D, Burns AJ, Itasaki N, Dattani M \& Martinez-Barbera JP 2007 Lack of the murine homeobox gene Hesxl leads to a posterior transformation of the anterior forebrain. Development 134 1499-1508. (doi:10.1242/dev.02829)

Bhangoo AP, Hunter CS, Savage JJ, Anhalt H, Pavlakis S, Walvoord EC, Ten S \& Rhodes SJ 2006 Clinical case seminar: a novel LHX3 mutation presenting as combined pituitary hormonal deficiency. Journal of Clinical Endocrinology and Metabolism 91 747-753. (doi:10. 1210/jc.2005-2360)

Brickman JM, Clements M, Tyrell R, McNay D, Woods K, Warner J, Stewart A, Beddington RS \& Dattani M 2001 Molecular effects of novel mutations in Hesx1/HESX1 associated with human pituitary disorders. Development 128 5189-5199.

Carlomagno Y, Salerno M, Vivenza D, Capalbo D, Godi M, Mellone S, Tiradani L, Corneli G, Momigliano-Richiardi P, Bona G et al. 2009 A novel recessive splicing mutation in the POU1F1 gene causing combined pituitary hormone deficiency. Journal of Endocrinological Investigation 32 653-658.

Carvalho LR, Woods KS, Mendonca BB, Marcal N, Zamparini AL, Stifani S, Brickman JM, Arnhold IJ \& Dattani MT 2003 A homozygous mutation in HESX1 is associated with evolving hypopituitarism due to impaired repressor-corepressor interaction. Journal of Clinical Investigation 112 1192-1201. (doi:10.1172/ JCI18589)

Carvalho LR, Brinkmeier ML, Castinetti F, Ellsworth BS \& Camper SA 2010 Corepressors TLE1 and TLE3 interact with HESX1 and PROP1. Molecular Endocrinology 24 754-765. (doi:10.1210/me.2008-0359)

Castinetti F, Saveanu A, Reynaud R, Quentien MH, Buffin A, Brauner R, Kaffel N, Albarel F, Guedj AM, El Kholy M et al. 2008 A novel dysfunctional LHX4 mutation with high phenotypical variability in patients with hypopituitarism. Journal of Clinical Endocrinology and Metabolism 93 2790-2799. (doi:10.1210/jc.2007-2389)

Cohen LE, Radovick S \& Wondisford FE $1999 a$ Transcription factors and hypopituitarism. Trends in Endocrinology $\mathcal{E}$ Metabolism 10 326-332. (doi:10.1016/S1043-2760(99)00180-0)

Cohen LE, Zanger K, Brue T, Wondisford FE \& Radovick S $1999 b$ Defective retinoic acid regulation of the pit- 1 gene enhancer: a novel mechanism of combined pituitary hormone deficiency. Molecular Endocrinology 13 476-484. (doi:10.1210/me.13.3.476)

Coya R, Vela A, Perez de Nanclares G, Rica I, Castano L, Busturia MA, Martul P \& GEDPIT group 2007 Panhypopituitarism: genetic versus acquired etiological factors. Journal of Pediatric Endocrinology $\mathcal{E}$ Metabolism 20 27-36.

Dasen JS \& Rosenfeld MG 2001 Signaling and transcriptional mechanisms in pituitary development. Annual Review of Neuroscience 24 327-355. (doi:10.1146/annurev.neuro.24.1.327)

Dateki S, Fukami M, Sato N, Muroya K, Adachi M \& Ogata T 2008 OTX2 mutation in a patient with anophthalmia, short stature, and partial growth hormone deficiency: functional studies using the IRBP, HESX1, and POU1F1 promoters. Journal of Clinical Endocrinology and Metabolism 93 3697-3702. (doi:10.1210/jc.2008-0720)

Dateki S, Kosaka K, Hasegawa K, Tanaka H, Azuma N, Yokoya S, Muroya K, Adachi M, Tajima T, Motomura K et al. 2009 Heterozygous orthodenticle homeobox 2 mutations are associated with variable pituitary phenotype. Journal of Clinical Endocrinology and Metabolism 95 756-764. (doi:10.1210/jc.2009-1334)
Dattani MT, Martinez-Barbera JP, Thomas PQ, Brickman JM, Gupta R, Martensson IL, Toresson H, Fox M, Wales JK, Hindmarsh PC et al. 1998 Mutations in the homeobox gene HESX1/Hesx1 associated with septo-optic dysplasia in human and mouse. Nature Genetics 19 125-133. (doi:10.1038/477)

Diaczok D, Romero C, Zunich J, Marshall I \& Radovick S 2008 A novel dominant negative mutation of OTX2 associated with combined pituitary hormone deficiency. Journal of Clinical Endocrinology and Metabolism 93 4351-4359. (doi:10.1210/jc.2008-1189)

Duquesnoy P, Roy A, Dastot F, Ghali I, Teinturier C, Netchine I, Cacheux V, Hafez M, Salah N, Chaussain JL et al. 1998 Human prop-1: cloning, mapping, genomic structure. Mutations in familial combined pituitary hormone deficiency. FEBS Letters 437 216-220. (doi:10.1016/S0014-5793(98)01234-4)

Gaston-Massuet C, Andoniadou CL, Signore M, Sajedi E, Bird S, Turner JM \& Martinez-Barbera JP 2008 Genetic interaction between the homeobox transcription factors HESX1 and SIX3 is required for normal pituitary development. Developmental Biology 324 322-333. (doi:10.1016/j.ydbio.2008.08.008)

Henderson RH, Williamson KA, Kennedy JS, Webster AR, Holder GE, Robson AG, FitzPatrick DR, van Heyningen V \& Moore AT 2009 A rare de novo nonsense mutation in OTX2 causes early onset retinal dystrophy and pituitary dysfunction. Molecular Vision 15 2442-2447.

Hermesz E, Mackem S \& Mahon KA 1996 Rpx: a novel anteriorrestricted homeobox gene progressively activated in the prechordal plate, anterior neural plate and Rathke's pouch of the mouse embryo. Development 122 41-52.

Kato Y, Kimoto F, Susa T, Nakayama M, Ishikawa A \& Kato T 2010 Pituitary homeodomain transcription factors HESX1 and PROP1 form a heterodimer on the inverted TAAT motif. Molecular and CellularEndocrinology 315 168-173. (doi:10.1016/j.mce.2009.10.006)

Kelberman D \& Dattani MT 2006 The role of transcription factors implicated in anterior pituitary development in the aetiology of congenital hypopituitarism. Annals of Medicine 38 560-577. (doi:10.1080/07853890600994963)

Kelberman D \& Dattani MT 2007 Hypopituitarism oddities: congenital causes. Hormone Research 68 (Supplement 5) 138-144. (doi:10.1159/ 000110610)

Kelberman D, Rizzoti K, Avilion A, Bitner-Glindzicz M, Cianfarani S, Collins J, Chong WK, Kirk JM, Achermann JC, Ross R et al. 2006 Mutations within Sox2/SOX2 are associated with abnormalities in the hypothalamo-pituitary-gonadal axis in mice and humans. Journal of Clinical Investigation 116 2442-2455. (doi:10.1172/ JCI28658)

Kelberman D, Turton J, Woods K, Mehta A, Al-Khawari M, Greening J, Swift P, Otonkoski T, Rhodes S \& Dattani M 2008a Molecular analysis of novel PROP1 mutations associated with combined pituitary hormone deficiency. Clinical Endocrinology 70 96-103. (doi:10.1111/j.1365-2265.2008.03326.x)

Kelberman D, de Castro SC, Huang S, Crolla JA, Palmer R, Gregory JW, Taylor D, Cavallo L, Faienza MF, Fischetto R et al. 2008b SOX2 plays a critical role in the pituitary, forebrain, and eye during human embryonic development. Journal of Clinical Endocrinology and Metabolism 93 1865-1873. (doi:10.1210/jc.2007-2337)

Kelberman D, Rizzoti K, Lovell-Badge R, Robinson IC \& Dattani MT 2009 Genetic regulation of pituitary gland development in human and mouse. Endocrine Reviews 30 790-829. (doi:10.1210/er.20090008)

Kristrom B, Zdunek AM, Rydh A, Jonsson H, Sehlin P \& Escher SA 2009 A novel mutation in the LHX3 gene is responsible for combined pituitary hormone deficiency, hearing impairment, and vertebral malformations. Journal of Clinical Endocrinology and Metabolism 94 1154-1161. (doi:10.1210/jc.2008-0325)

Kurokawa D, Kiyonari H, Nakayama R, Kimura-Yoshida C, Matsuo I \& Aizawa S 2004 Regulation of Otx2 expression and its functions in mouse forebrain and midbrain. Development 131 3319-3331. (doi:10. $1242 /$ dev.01220) 
Lemos MC, Gomes L, Bastos M, Leite V, Limbert E, Carvalho D, Bacelar C, Monteiro M, Fonseca F, Agapito A et al. 2006 PROP1 gene analysis in Portuguese patients with combined pituitary hormone deficiency. Clinical Endocrinology 65 479-485. (doi:10.1111/j.13652265.2006.02617.x)

Liu Y, Fan M, Yu S, Zhou Y, Wang J, Yuan J \& Qiang B 2002 cDNA cloning, chromosomal localization and expression pattern analysis of human LIM-homeobox gene LHX4. Brain Research 928 147-155. (doi:10.1016/S0006-8993(01)03243-7)

Machinis K \& Amselem S 2005 Functional relationship between LHX4 and POU1F1 in light of the LHX4 mutation identified in patients with pituitary defects. Journal of Clinical Endocrinology and Metabolism 90 5456-5462. (doi:10.1210/jc.2004-2332)

Machinis K, Pantel J, Netchine I, Leger J, Camand OJ, Sobrier ML, Dastot-Le Moal F, Duquesnoy P, Abitbol M, Czernichow P et al. 2001 Syndromic short stature in patients with a germline mutation in the LIM homeobox LHX4. American Journal of Human Genetics 69 961-968. (doi:10.1086/323764)

McGillivray SM, Bailey JS, Ramezani R, Kirkwood BJ \& Mellon PL 2005 Mouse GnRH receptor gene expression is mediated by the LHX3 homeodomain protein. Endocrinology 146 2180-2185. (doi:10.1210/ en.2004-1566)

McNay DE, Turton JP, Kelberman D, Woods KS, Brauner R, Papadimitriou A, Keller E, Keller A, Haufs N, Krude H et al. 2007 HESX1 mutations are an uncommon cause of septooptic dysplasia and hypopituitarism. Journal of Clinical Endocrinology and Metabolism 92 691-697. (doi:10.1210/jc.2006-1609)

Miyata I, Vallette-Kasic S, Saveanu A, Takeuchi M, Yoshikawa H, Tajima A, Tojo K, Reynaud R, Gueydan M, Enjalbert A et al. 2006 Identification and functional analysis of the novel S179R POU1F1 mutation associated with combined pituitary hormone deficiency. Journal of Clinical Endocrinology and Metabolism 91 4981-4987. (doi:10.1210/jc.2005-2289)

Olson LE, Tollkuhn J, Scafoglio C, Krones A, Zhang J, Ohgi KA, Wu W, Taketo MM, Kemler R, Grosschedl R et al. 2006 Homeodomainmediated beta-catenin-dependent switching events dictate celllineage determination. Cell 125 593-605. (doi:10.1016/j.cell.2006. 02.046)

Pfaeffle RW, Savage JJ, Hunter CS, Palme C, Ahlmann M, Kumar P, Bellone J, Schoenau E, Korsch E, Bramswig JH et al. 2007 Four novel mutations of the LHX3 gene cause combined pituitary hormone deficiencies with or without limited neck rotation. Journal of Clinical Endocrinology and Metabolism 92 1909-1919. (doi:10.1210/jc.20062177)

Pfaeffle RW, Hunter CS, Savage JJ, Duran-Prado M, Mullen RD, Neeb ZP, Eiholzer U, Hesse V, Haddad NG, Stobbe HM et al. 2008 Three novel missense mutations within the LHX4 gene are associated with variable pituitary hormone deficiencies. Journal of Clinical Endocrinology and Metabolism 93 1062-1071. (doi:10.1210/jc.2007-1525)

Qi Y, Ranish JA, Zhu X, Krones A, Zhang J, Aebersold R, Rose DW, Rosenfeld MG \& Carriere C 2008 Atbfl is required for the Pitl gene early activation. PNAS 105 2481-2486. (doi:10.1073/pnas. 0712196105)

Rajab A, Kelberman D, de Castro SC, Biebermann H, Shaikh H, Pearce K, Hall CM, Shaikh G, Gerrelli D, Grueters A et al. 2008 Novel mutations in LHX3 are associated with hypopituitarism and sensorineural hearing loss. Human Molecular Genetics 17 2150-2159. (doi:10.1093/hmg/ddn114)

Reynaud R, Saveanu A, Barlier A, Enjalbert A \& Brue T 2004 Pituitary hormone deficiencies due to transcription factor gene alterations. Growth Hormone E $I G F$ Research 14 442-448. (doi:10.1016/j.ghir. 2004.07.001)

Reynaud R, Gueydan M, Saveanu A, Vallette-Kasic S, Enjalbert A, Brue T \& Barlier A 2006 Genetic screening of combined pituitary hormone deficiency: experience in 195 patients. Journal of Clinical Endocrinology and Metabolism 91 3329-3336. (doi:10.1210/jc.2005-2173)

Roessler E, Du YZ, Mullor JL, Casas E, Allen WP, Gillessen-Kaesbach G, Roeder ER, Ming JE, Ruiz i Altaba A \& Muenke M 2003
Loss-of-function mutations in the human GLI2 gene are associated with pituitary anomalies and holoprosencephaly-like features. PNAS 100 13424-13429. (doi:10.1073/pnas.2235734100)

Rosenfeld MG 1991 POU-domain transcription factors: pou-er-ful developmental regulators. Genes and Development 5 897-907. (doi:10.1101/gad.5.6.897)

Sajedi E, Gaston-Massuet C, Andoniadou CL, Signore M, Hurd PJ, Dattani M \& Martinez-Barbera JP 2008a DNMT1 interacts with the developmental transcriptional repressor HESX1. Biochimica et Biophysica Acta 1783 131-143. (doi:10.1016/j.bbamcr.2007.08.010)

Sajedi E, Gaston-Massuet C, Signore M, Andoniadou CL, Kelberman D, Castro S, Etchevers HC, Gerrelli D, Dattani MT \& Martinez-Barbera JP $2008 b$ Analysis of mouse models carrying the I26T and R160C substitutions in the transcriptional repressor HESX1 as models for septo-optic dysplasia and hypopituitarism. Disease Models $\mathcal{E}^{\circ}$ Mechanisms 1 241-254. (doi:10.1242/dmm.000711)

Schilter KF, Schneider A, Bardakjian T, Soucy JF, Tyler RC, Reis LM \& Semina EV 2010 OTX2 microphthalmia syndrome: four novel mutations and delineation of a phenotype. Clinical Genetics $\mathbf{7 9}$ 158-168. (doi:10.1111/j.1399-0004.2010.01450.x)

Scully KM \& Rosenfeld MG 2002 Pituitary development: regulatory codes in mammalian organogenesis. Science 295 2231-2235. (doi:10. 1126/science.1062736)

Sheng HZ, Moriyama K, Yamashita T, Li H, Potter SS, Mahon KA \& Westphal H 1997 Multistep control of pituitary organogenesis. Science 278 1809-1812. (doi:10.1126/science.278.5344.1809)

Sloop KW, Meier BC, Bridwell JL, Parker GE, Schiller AM \& Rhodes SJ 1999 Differential activation of pituitary hormone genes by human Lhx3 isoforms with distinct DNA binding properties. Molecular Endocrinology 13 2212-2225. (doi:10.1210/me.13.12.2212)

Sloop KW, Dwyer CJ \& Rhodes SJ 2001 An isoform-specific inhibitory domain regulates the LHX3 LIM homeodomain factor holoprotein and the production of a functional alternate translation form. Journal of Biological Chemistry 276 36311-36319. (doi:10.1074/jbc. M103888200)

Snabboon T, Plengpanich W, Buranasupkajorn P, Khwanjaipanich R, Vasinanukorn P, Suwanwalaikorn S, Khovidhunkit W \& Shotelersuk V 2008 A novel germline mutation, IVS4 + 1G > A, of the POU1F1 gene underlying combined pituitary hormone deficiency. Hormone Research 69 60-64. (doi:10.1159/000111797)

Sobrier ML, Maghnie M, Vie-Luton MP, Secco A, di Iorgi N, Lorini R \& Amselem S 2006 Novel HESX1 mutations associated with a lifethreatening neonatal phenotype, pituitary aplasia, but normally located posterior pituitary and no optic nerve abnormalities. Journal of Clinical Endocrinology and Metabolism 91 4528-4536. (doi:10.1210/jc.2006-0426)

Solomon NM, Ross SA, Forrest SM, Thomas PQ, Morgan T, Belsky JL, Hol FA, Karnes PS, Hopwood NJ, Myers SE et al. 2007 Array comparative genomic hybridisation analysis of boys with X-linked hypopituitarism identifies a $3.9 \mathrm{mb}$ duplicated critical region at Xq27 containing SOX3. Journal of Medical Genetics 44 e75. (doi:10. 1136/jmg.2007.049049)

Sornson MW, Wu W, Dasen JS, Flynn SE, Norman DJ, O'Connell SM, Gukovsky I, Carriere C, Ryan AK, Miller AP et al. 1996 Pituitary lineage determination by the prophet of pit- 1 homeodomain factor defective in ames dwarfism. Nature 384 327-333. (doi:10.1038/ $384327 \mathrm{a} 0$ )

Tajima T, Hattorri T, Nakajima T, Okuhara K, Sato K, Abe S, Nakae J \& Fujieda K 2003 Sporadic heterozygous frameshift mutation of HESX1 causing pituitary and optic nerve hypoplasia and combined pituitary hormone deficiency in a Japanese patient. Journal of Clinical Endocrinology and Metabolism 88 45-50. (doi:10.1210/jc.2002020818)

Tajima T, Yorifuji T, Ishizu K \& Fujieda K $2009 a$ A novel mutation (V101A) of the LHX4 gene in a Japanese patient with combined pituitary hormone deficiency. Experimental and Clinical Endocrinology Ev Diabetes 118 405-409. (doi:10.1055/s-0029-1225612) 
Tajima T, Ohtake A, Hoshino M, Amemiya S, Sasaki N, Ishizu K \& Fujieda K $2009 b$ OTX2 loss of function mutation causes anophthalmia and combined pituitary hormone deficiency with a small anterior and ectopic posterior pituitary. Journal of Clinical Endocrinology and Metabolism 94 314-319. (doi:10.1210/jc.2008-1219)

Tatsumi K, Miyai K, Notomi T, Kaibe K, Amino N, Mizuno Y \& Kohno H 1992 Cretinism with combined hormone deficiency caused by a mutation in the PIT1 gene. Nature Genetics $156-58$. (doi:10.1038/ng0492-56)

Thomas P \& Beddington R 1996 Anterior primitive endoderm may be responsible for patterning the anterior neural plate in the mouse embryo. Current Biology 6 1487-1496. (doi:10.1016/S0960-9822(96) 00753-1)

Thomas PQ, Dattani MT, Brickman JM, McNay D, Warne G, Zacharin M, Cameron F, Hurst J, Woods K, Dunger D et al. 2001 Heterozygous HESX1 mutations associated with isolated congenital pituitary hypoplasia and septo-optic dysplasia. Human Molecular Genetics 10 39-45. (doi:10.1093/hmg/10.1.39)

Turton JP, Mehta A, Raza J, Woods KS, Tiulpakov A, Cassar J, Chong K, Thomas PQ, Eunice M, Ammini AC et al. 2005a Mutations within the transcription factor PROP1 are rare in a cohort of patients with sporadic combined pituitary hormone deficiency (CPHD). Clinical Endocrinology 63 10-18. (doi:10.1111/j.1365-2265.2005.02291.x)

Turton JP, Reynaud R, Mehta A, Torpiano J, Saveanu A, Woods KS, Tiulpakov A, Zdravkovic V, Hamilton J, Attard-Montalto $\mathrm{S} e t$ al. $2005 b$ Novel mutations within the POU1F1 gene associated with variable combined pituitary hormone deficiency. Journal of Clinical Endocrinology and Metabolism 90 4762-4770. (doi:10.1210/jc.20050570)

Ward RD, Davis SW, Cho M, Esposito C, Lyons RH, Cheng JF, Rubin EM, Rhodes SJ, Raetzman LT, Smith TP et al. 2007 Comparative genomics reveals functional transcriptional control sequences in the Propl gene. Mammalian Genome 18 521-537. (doi:10.1007/ s00335-007-9008-6)

West BE, Parker GE, Savage JJ, Kiratipranon P, Toomey KS, Beach LR, Colvin SC, Sloop KW \& Rhodes SJ 2004 Regulation of the folliclestimulating hormone beta gene by the LHX3 LIM-homeodomain transcription factor. Endocrinology 145 4866-4879. (doi:10.1210/en. 2004-0598)

Woods KS, Cundall M, Turton J, Rizotti K, Mehta A, Palmer R, Wong J, Chong WK, Al-Zyoud M, El-Ali M et al. 2005 Over- and underdosage of SOX3 is associated with infundibular hypoplasia and hypopituitarism. American Journal of Human Genetics 76 833-849. (doi:10. 1086/430134)

Xu L, Lavinsky RM, Dasen JS, Flynn SE, McInerney EM, Mullen TM, Heinzel T, Szeto D, Korzus E, Kurokawa R et al. 1998 Signal-specific co-activator domain requirements for pit-1 activation. Nature 395 301-306. (doi:10.1038/26270)

Zhu X, Zhang J, Tollkuhn J, Ohsawa R, Bresnick EH, Guillemot F, Kageyama R \& Rosenfeld MG 2006 Sustained notch signaling in progenitors is required for sequential emergence of distinct cell lineages during organogenesis. Genes and Development 20 2739-2753. (doi:10.1101/gad.1444706)

Zhu X, Wang J, Ju BG \& Rosenfeld MG 2007 Signaling and epigenetic regulation of pituitary development. Current Opinion in Cell Biology 19 605-611. (doi:10.1016/j.ceb.2007.09.011)

Received in final form 17 March 2011

Accepted 28 March 2011

Made available online as an Accepted Preprint 29 March 2011 